\title{
Virtual Tour Panorama 360 Derajat Kampus Universitas Sam Ratulangi Manado
}

\author{
Fahri R. Daud, Virginia Tulenan, Xaverius B. N. Najoan \\ Teknik Informatika Universitas Sam Ratulangi Manado, Indonesia. \\ Fahridaud350@gmail.com, Virginiatulenan@gmail.com,Xnajoan@unsrat.ac.id
}

\begin{abstract}
Abstrak - Universitas Sam Ratulangi Manado merupakan perguruan tinggi terbesar di Sulawesi Utara. Dan setiap tahun bertambahnya mahasiswa baru di Universitas Sam Ratulangi Manado yang datang dari dalam maupun luar provinsi Sulawesi Utara. Calon mahasiswa dari berbagai daerah tentunya banyak yang mencari informasi wilayah kampus baik fakultas, jurusan, dan program studi melalui media yang ada. Melihat hal tersebut, maka dibuatlah sebuah media Virtual Tour panorama $360^{\circ}$ kampus Universitas Sam Ratulangi Manado berbasis website, saat ini sudah banyak yang menggunakan teknologi Virtual Tour tersebut dalam industri, pendidikan, jurnalisme, bisnis, dan lain sebagainya, untuk sebagai media informasi visual yang efektif dan interaktif. Dalam penelitian ini dilakukan kombinasi antara gambar panorama $360^{\circ}$ dengan video yang akan dipublikasikan ke website Unsrat dan menggunakan fasilitas Google Maps dan Google Street View sehingga pengguna dapat melihat informasi lokasi visual secara online dengan mengakses situs resmi https://maps.google.com dengan kata kunci Unsrat. Pengembangan sistem dalam penelitian ini menggunakan metode pengembangan Luther Hadi Sutopo, melalui tahapan concept, desaign, material collecting, assembly, testing, dan distribution. Dalam aplikasi Virtual Tour kampus ini pengguna dapat melihat lingkungan kampus secara visual dengan pandangan panorama $360^{\circ}$. Selain itu, pengguna juga dapat berjalan-jalan ke 29 lokasi yang ada di kampus Universitas Sam Ratulangi Manado menggunakan tombol yang disediakan. Aplikasi Virtual Tour kampus ini telah melewati proses pengujian, dan berfungsi sesuai yang diharapkan.
\end{abstract}

Kata kunci : Google Maps, Panorama $360^{\circ}$, Universitas Sam Ratulangi, Virtual Tour

\section{PENDAHULUAN}

Perkembangan teknologi yang saat ini berkembang semakin hari semakin pesat, sehingga memunculkan banyak inovasi baru dari teknologi, salah satu inovasi yang dapat kita jumpai teknologi yang berkembang saat ini adalah teknologi Virtual Tour. Dalam jurnal yang disusun oleh Osman, Wahab dan Ismail (2009, p173), Virtual Tour merupakan teknologi yang menempatkan user di dalam gambar dan memungkinkan user untuk meningkatkan kesadaran situasional serta meningkatkan daya lihat, tangkap dan menganalisa data virtual secara signifikan.

Universitas Sam Ratulangi Manado merupakan Perguruan tinggi terbesar di Sulawesi Utara ini berdiri sejak tahun 1961, bermula hanya dengan beberapa Fakultas, kini Universitas yang dikenal dengan sebutan UNSRAT ini telah berkembang menjadi 11 Fakultas dengan 47 program S1, dan 27 program Pasca Sarjana yang terdiri atas S2, S3, Profesi, dan Spesialis. Secara total terdapat 74 Program Studi, dari S1 sampai S3 spesialis. Dan setiap tahun bertambahnya mahasiswa baru di Unsrat, calon mahasiswa dari berbagai daerah tentuya banyak yang mencari informasi wilayah Kampus baik Fakultas, Jurusan dan Program Studi melalui media yang ada. Dalam skripsi ini penulis mencoba membuat aplikasi Virtual Tour kampus Unsrat Manado untuk mengembangkan konsep Sistem Multimedia yaitu mengkombinasikan media diskrit yaitu gambar panorama $360^{\circ}$ dan media kontinu yaitu video.

\section{LANDASAN TEORI}

\section{A. Virtual Tour}

Dalam jurnal yang disusun oleh Osman, Wahab dan Ismail (2009, p173), Virtual Tour merupakan teknologi yang menempatkan user di dalam gambar dan memungkinkan user untuk meningkatkan kesadaran situasional serta meningkatkan daya lihat, tangkap dan menganalisa data virtual secara signifikan. ${ }^{[1]}$

Virtual Tour merupakan sebuah simulasi dari sebuah lokasi yang terdiri dari rentetan. Rentetan gambar tersebut akan digabungkan (stitch) untuk menghasilkan foto panorama 360 derajat. Virtual Tour sendiri biasanya digunakan untuk memberi pengalaman 'pernah berada' di suatu tempat hanya dengan melihat layar monitor. Penyajian virtual tour dapat dilakukan dengan cara memanfaatkan gambar ataupun video, selain itu dapat menggunakan model 3dimensi. Untuk penyajian dengan menggunakan gambar, dapat digunakan foto panorama. Pemilihan jenis foto panorama juga mempengaruhi hasil virtual tour yang dihasilkan. Untuk panorama jenis cylindrical, bagian vertikalnya hanya dapat menangkap tidak lebih dari 180 
derajat sedangkan jenis spherical, memungkinkan untuk melihat ke atas dan ke bawah. ${ }^{[2]}$

\section{B. Multimedia}

Menurut Vaughan (2010), multimedia merupakan kombinasi teks, seni, suara, gambar, animasi, dan video yang disampaikan dengan komputer atau dimanipulasi secara digital dan dapat disampaikan atau dikontrol secara interaktif. Ada tiga jenis multimedia, yaitu :

\section{Multimedia interaktif}

Pengguna dapat mengontrol apa dan kapan elemen-elemen multimedia akan dikirimkan atau ditampilkan.

2. Multimedia hiperaktif

Multimedia jenis ini mempunyai suatu struktur dari elemenelemen terkait dengan pengguna yang dapat mengarahkannya. Dapat dikatakan bahwa multimedia jenis ini mempunyai banyak tautan (link) yang menghubungkan elemen-elemen multimedia yang ada.

\section{Multimedia linear}

Pengguna hanya menjadi penonton dan menikmati produk multimedia yang disajikan dari awal hingga akhir. ${ }^{[6]}$

\section{PTGui}

PTGui adalah panorama software image jahitan untuk windows dan Mac OS X. Awalnya dimulai sebagai user graphical interface untuk tools panorama, PTGui telah berkembang menjadi fitur, industri terkemuka foto aplikasi jahitan penuh. PTGui mampu menjahit panorama 1 Gigapixel di sekitar 25 detik pada hardware sederhana. Hanya drop foto Anda ke dalam PTGui dan akan mencari tahu bagaimana tumpang tindih. PTGui bisa menjahit beberapa baris dari gambar dan mendukung semua lensa, termasuk Fisheyes. PTGui memberi kontrol penuh atas hasilnya, memungkinkan untuk membuat panorama sempurna bahkan adegan yang sulit, di mana stitchers lain gagal. Panorama bola Buat sepenuhnya bulat $360^{\circ} \times 180^{\circ}$ panorama. ${ }^{[4]}$

\section{Easypano Tourweafer}

Easypano Tourweafer didirikan pada bulan november 2011, di Sanghai, Cina. easypano menyediakan dua jenis solusi imaging mendalam sejauh satu tur virtual dan yang lainnya adalah film objek, profesional virtual tour software Tourweaver, tur mandiri executable menciptakan software Tourweaver, dan HTML5 sederhana dan Flash panorama penerbitan EPublisher dengan peranti lunak. ${ }^{[5]}$

\section{E. Metode Luther Sutopo}

Menurut Luther (1994), tahapan-tahapan dengan metodologi pengembangan multimedia tidak perlu berurutan. Dari keenam tahapannya dapat saling bertukar posisi, namun tetap dimulai dari konsep terlebih dahulu dan diakhiri dengan tahap distribusi. ${ }^{[3]}$
Sutopo mengadopsi metode Luther dengan memodifikasi tahapan - tahapannya, dari keenam tahapan Luther. Tahapan concept, desain, material collecting, assembly, testing, distribution, harus dimulai dimulai dari consept dan diakhiri dengan tahap distribusi, sedangkan tahap Material Collection dapat dikerjakan secara parallel dengan tahap Assembly.( Sutopo, A.H, 2003).

\section{METODOLOGI PENELITIAN}

Sesuai dengan Gambar 1 metode pengembangan sistem dalam penelitian ini menggunakan metode Luther Sutopo, sehingga fase dalam penelitian yang dilakukan adalah sebagai berikut :

Metodologi Luther Sutopo, terdiri dari 6 tahap yaitu, Tahap Concept, Tahap Design, Tahap Material, Tahap Collecting, Tahap Assembly, Tahap Testing, dan Tahap Distribution. Menurut Luther (1994), tahapan-tahapan dengan metodologi pengembangan multimedia tidak perlu berurutan dari keenam tahapannya dapat saling bertukar posisi, namun tetap dimulai dari konsep terlebih dahulu dan diakhiri dengan tahap distribusi. Keenam tahap ini akan dibahas menjadi 2 bagian, yaitu Tahap Concept, Tahap Desaign, Tahap Material Collecing akan di bahas di bab 3 dan sisanya yaitu Tahap Assembly, Tahap Testing dan Tahap Distribution akan dibahas di bab 4 hasil dan pembahasan.

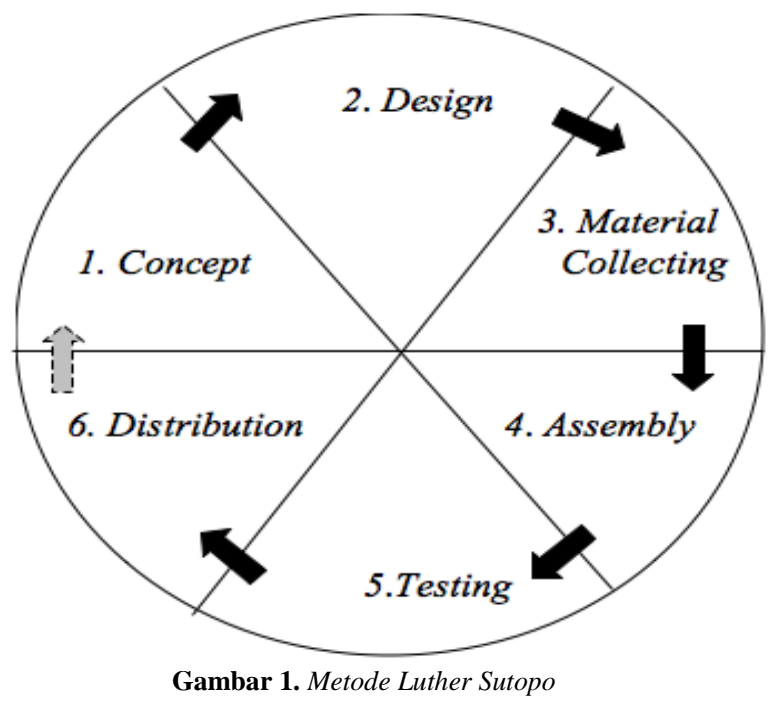

Sumber : Sutopo, Ariesto Hadi.(2003) 


\section{A. Concept}

TABEL I

KONSEP

\begin{tabular}{|l|l|}
\hline Judul & $\begin{array}{l}\text { Virtual Tour Panorama } 360^{\circ} \text { Kampus } \\
\text { Universitas Sam Ratulangi Manado }\end{array}$ \\
\hline Tujuan & $\begin{array}{l}\text { Memperkenalkan lingkungan Kampus } \\
\text { Unsrat Manado dan memberikan } \\
\text { informasi secara visual dengan foto } \\
\text { pandangan } 360^{\circ} .\end{array}$ \\
\hline Pengguna akhir & Mahasiswa Unsrat dan masyarakat umum \\
\hline Objek Virtual & $\begin{array}{l}\text { Konten-konten multimedia yaitu foto dan } \\
\text { video }\end{array}$ \\
\hline Input & Foto, Teks, dan Video \\
\hline Output & Foto 360 dan teks \\
\hline
\end{tabular}

\section{B. Desaign}

Use Case diagram Gambar 2 menggambarkan fungsionalitas dari sebuah sistem, pada aplikasi Virtual Tour Kampus ini user dapat melakukan aktivitas melihat halaman awal, melihat tampilan 360, menjalankan Virtual Tour, melihat gambar lokasi Virtual Tour, melihat Bing Map, melihat peta plan kampus, memutar music, mematikan suara audio dan video, mengukur kecepatan 360, memutar kiri kanan atas dan bawah, mengatur zoom in dan zoom out.

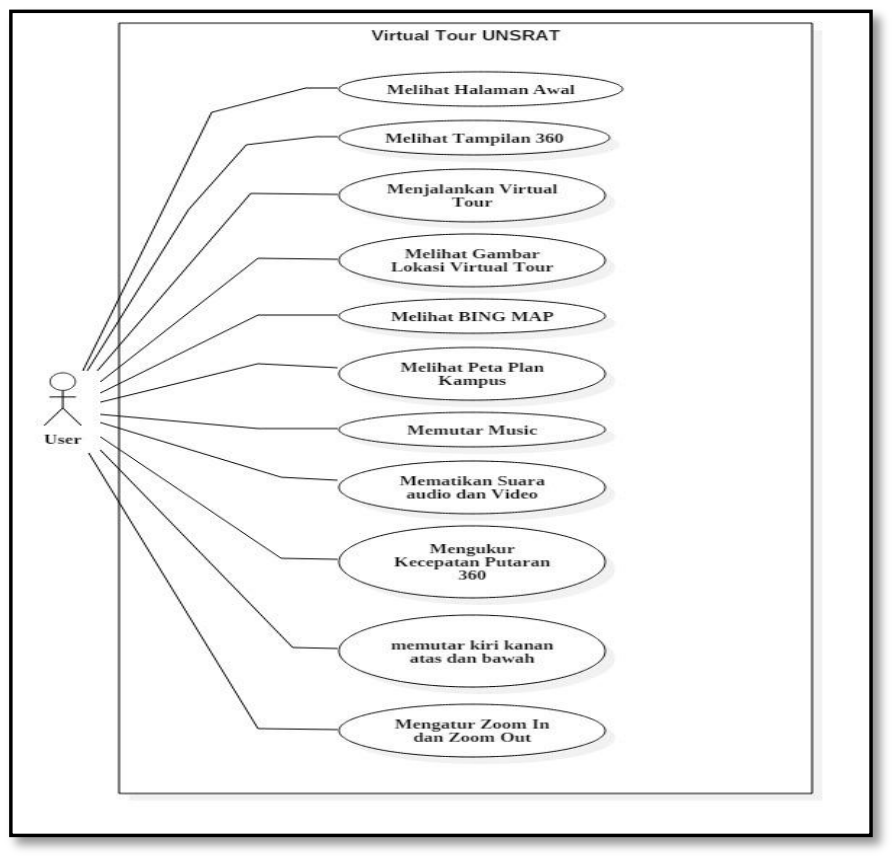

Gambar 2. Use Case
Tabel II Activity Diagram Virtual Tour Kampus Unsrat menjelaskan aktivitas bagaimana user menggunakan fiturfitur yang tersedia pada aplikasi tersebut

Tabel II

ACTIVITY DIAGRAM

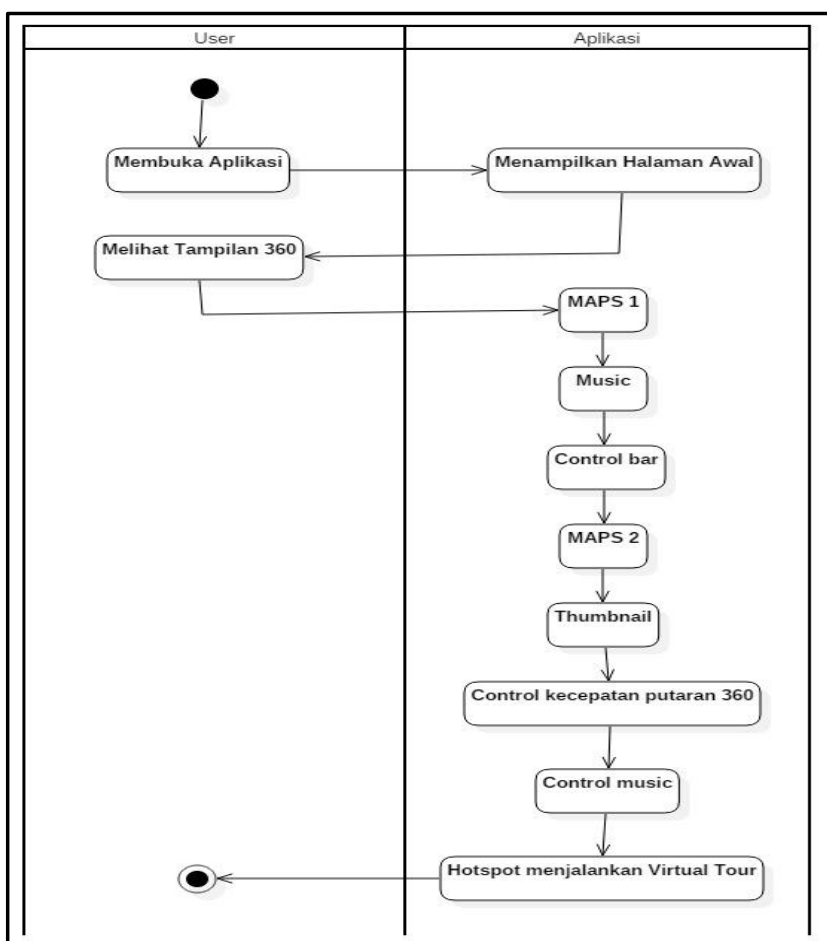

TABEL III

STORYBOARD APLIKASI

\begin{tabular}{|c|c|c|}
\hline SCENE & VISUAL & DESKRIPSI \\
\hline 1 & 1. & $\begin{array}{l}\text { Tampilan Loading adalah } \\
\text { tampilan awal untuk masuk } \\
\text { ke Aplikasi Virtual Tour, } \\
\text { loading } \\
\text { menggunakan foto kantor } \\
\text { pusat Unsrat. }\end{array}$ \\
\hline 2 & Phoreman 360 & $\begin{array}{l}\text { Halaman awal aplikasi } \\
\text { Virtual Tour adalah gambar } \\
\text { panorama } 360^{\circ} \text { dan terdapat } 7 \\
\text { buah button yaitu : control } \\
\text { bar, music, map, control } \\
\text { putaran 360, control audio, } \\
\text { thumbnail, dan peta kampus. }\end{array}$ \\
\hline
\end{tabular}




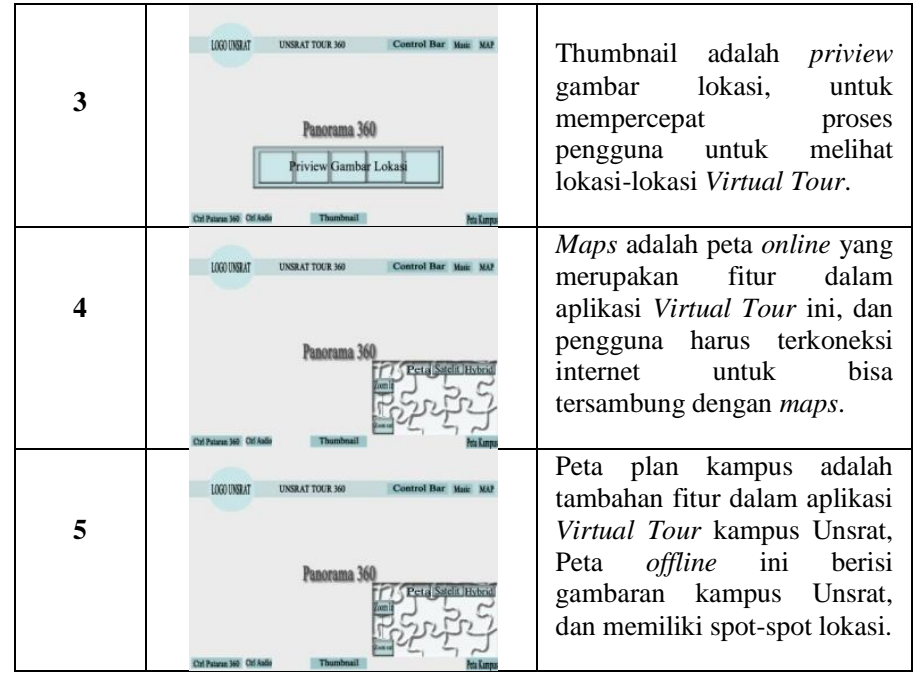

\section{Material Collecting}

\section{Interview (wawancara)}

Wawancara yang dilakukan dalam penelitian ini yaitu, melakukan tanya jawab kepada mahasiswa Universitas Sam Ratulangi Manado, untuk mengetahui sejauh mana mahasiswa mengenal lingkungan Kampus Unsrat, dan apakah mahasiswa memerlukan sebuah sistem untuk mengenal lingkungan Kampus Unsrat. Responden diberikan pertanyaan tertulis dan dilengkapi alternatif jawaban.

\section{Kuesioner (Angket)}

Pada tahap ini yang dilakukan yaitu, membagikan kuesioner kepada mahasiswa Unsrat disebelas Fakultas, untuk mengetahui lokasi gedung utama di setiap Fakultas, dan untuk mengetahui apakah responden tertarik untuk menggunakan aplikasi Virtual Tour Kampus Unsrat. Tujuan hasil kuesioner untuk dijadikan lokasi Virtual Tour panorama 360 derajat.

\section{Observasi (Pengamatan)}

Dalam Penelitian ini, observasi digunakan untuk mengetahui sejau mana mahasiswa mengenal lingkungan kampus, dengan cara melakukan pengamatan langsung kepada mahasiswa UNSRAT. Data yang didapat oleh penulis yaitu dari kuesioner, untuk mengetahui lokasi yang perlu diperkenalkan di fakultasnya.
TABEL IV

PENGAMBILAN FOTO PANORAMA

\begin{tabular}{|c|c|c|c|c|c|}
\hline \multirow[b]{2}{*}{ No } & \multirow[b]{2}{*}{ Nama Tempat } & \multicolumn{3}{|c|}{ Foto } & \multirow[b]{2}{*}{$\begin{array}{c}\text { Jumlah } \\
\text { Foto }\end{array}$} \\
\hline & & Horizintal & Zenith & Nadir & \\
\hline 1 & $\begin{array}{l}\text { Depan kantor pusat } \\
\text { UNSRAT }\end{array}$ & 5 & 1 & 1 & 7 \\
\hline 2 & Perempatan FATEK & 7 & 1 & 1 & 9 \\
\hline 3 & Perempatan FEKON & 7 & 1 & 1 & 9 \\
\hline 4 & $\begin{array}{l}\text { Pertigaan samping } \\
\text { Bank BNI UNSRAT }\end{array}$ & 7 & 1 & 1 & 9 \\
\hline 5 & $\begin{array}{l}\text { Pertigaan Pasca } \\
\text { Sarjana UNSRAT }\end{array}$ & 7 & 1 & 1 & 9 \\
\hline 6 & Pertigaan pertanian 2 & 7 & 1 & 1 & 9 \\
\hline 7 & $\begin{array}{l}\text { Pertigaan samping } \\
\text { Bank BRI }\end{array}$ & 6 & 1 & 1 & 8 \\
\hline 8 & $\begin{array}{l}\text { Pertigaan Fakultas } \\
\text { perikanan dan ilmu } \\
\text { kelautan }\end{array}$ & 6 & 1 & 1 & 8 \\
\hline 9 & $\begin{array}{l}\text { Perempatan Fakultas } \\
\text { MIPA }\end{array}$ & 6 & 1 & 1 & 8 \\
\hline 10 & $\begin{array}{l}\text { Fakultas MIPA (Prodi } \\
\text { Farmasi) }\end{array}$ & 6 & 1 & 1 & 8 \\
\hline 11 & $\begin{array}{l}\text { Fakultas MIPA } \\
\text { (Samping SMA N } 9 \\
\text { Manado) }\end{array}$ & 7 & 1 & 1 & 9 \\
\hline 12 & $\begin{array}{l}\text { Fakultas Perikanan } \\
\text { (Kolam Ikan) }\end{array}$ & 5 & 1 & 1 & 7 \\
\hline 13 & $\begin{array}{l}\text { Fakultas Perikanan } \\
\text { (Lobby) }\end{array}$ & 6 & 1 & 1 & 8 \\
\hline 14 & $\begin{array}{l}\text { Pertigaan depan } \\
\text { Fakultas Pertanian }\end{array}$ & 6 & 1 & 1 & 8 \\
\hline 15 & Fakultas Pertanian & 4 & 1 & 1 & 6 \\
\hline 16 & $\begin{array}{l}\text { Pertigaan depan } \\
\text { Fakultas Peternakan }\end{array}$ & 7 & 1 & 1 & 9 \\
\hline 17 & Fakultas Peternakan & 6 & 1 & 1 & 8 \\
\hline 18 & $\begin{array}{l}\text { Fakultas Sastra dan } \\
\text { Ilmu Budaya }\end{array}$ & 5 & 1 & 1 & 7 \\
\hline 19 & Prodi Kedokteran Gigi & 5 & 1 & 1 & 7 \\
\hline 20 & $\begin{array}{l}\text { Fakultas Teknik } \\
\text { (Letter U) }\end{array}$ & 5 & 1 & 1 & 7 \\
\hline 21 & Depan Fakultas Teknik & 5 & 1 & 1 & 7 \\
\hline 22 & Fakultas Ekonomi dan & 5 & 1 & 1 & 7 \\
\hline
\end{tabular}




\begin{tabular}{|c|l|c|c|c|c|}
\hline & Bisnis (Gedung A) & & & & \\
\hline 23 & $\begin{array}{l}\text { Fakultas Ekonomi dan } \\
\text { Bisnis (Gedung } \\
\text { Kambuna) }\end{array}$ & 5 & 1 & 1 & 7 \\
\hline 24 & Fakultas Hukum & 5 & 1 & 1 & 7 \\
\hline 25 & FISIP (Gedung Baru) & 6 & 1 & 1 & 8 \\
\hline 26 & FISIP (Taman) & 5 & 1 & 1 & 7 \\
\hline 27 & FKM (Ikip Bawah) & 6 & 1 & 1 & 8 \\
\hline 28 & FKM (Pasca Sarjana) & 6 & 1 & 1 & 8 \\
\hline 29 & $\begin{array}{l}\text { Pasca Sarjana } \\
\text { UNSRAT }\end{array}$ & 10 & 1 & 1 & 12 \\
\hline
\end{tabular}

IV.HASIL DAN PEMBAHASAN

\section{Assembly}

Berdasarkan hasil kuisioner dan wawancara tertulis kepada mahasiswa UNSRAT, didapatkan lokasi gedung utama di sebelas Fakultas yang akan dibuat dalam aplikasi Virtual Tour. Selanjutnya melakukan pengambilan gambar pada lokasi-lokasi tersebut, dan dilakukan pengembangan dengan langkah-langkah antara lain pembuatan foto panorama dengan menggunakan software PTGui, dan di kembangkan lagi menggunakan software Tourweafer sehingga menjadi satu aplikasi Virtual Tour yang bisa menampilkan foto panorama $360^{\circ}$ serta menampilkan Bing Map dan peta plan kampus.

Setelah proses desain selesai maka desain tersebut dibuat acuan dalam tahap assembly, pada tahap assembly atau perakitan, foto-foto panorama yang telah di kumpulkan di olah dengan menggunakan software Tourweafer hingga menjadi 1 aplikasi Virtual Tour, di dalam aplikasi ini akan di tampilkan peta Universitas Sam Ratulangi Manado, dalam peta tersebut memiliki titik -titik spot lokasi apabila user mengklik titik spot maka akan menampilkan gambar lokasi tersebut dengan gambar panorama 360 derajat, dan pada gambar tersebut memiliki anak panah apabila user mengklik salah satu arah anak panah maka gambar panorama akan menuju ke halaman yang di klik user.

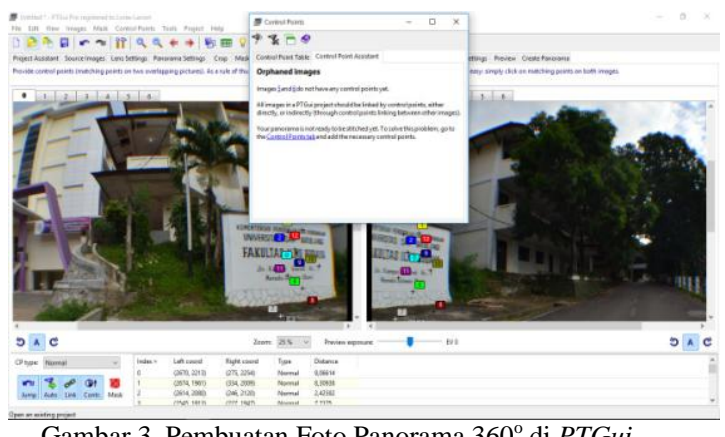

Gambar 3. Pembuatan Foto Panorama $360^{\circ}$ di PTGui

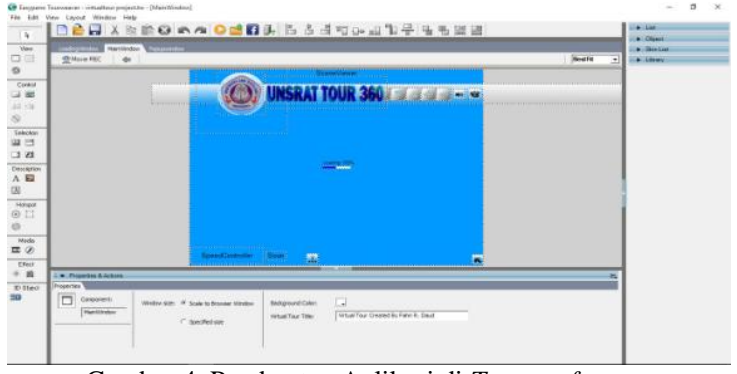

Gambar 4. Pembuatan Aplikasi di Tourweafer

(Gambar 3) Pembuatan foto panorama $360^{\circ}$ di PTGui, untuk menyatukan foto panorama $360^{\circ}$ di Aplikasi PTGui menggunakan teknik overlap yaitu gambar saling tumpa tindih dengan menentukan titik control poin untuk menyatukan gambar menjadi $360^{\circ}$.

(Gambar 4) Pembuatan Aplikasi di Tourweafer, setelah pembuatan foto panorama $360^{\circ}$ selesai kemudian dilakukan desain interface aplikasi Virtual Tour Kampus Unsrat di Tourweafer. foto-foto panorama $360^{\circ}$ tersebut dimasukan ke dalam aplikasi Tourweafer sehingga menjadi satu aplikasi Virtual Tour Kampus Unsrat Manado.

\section{E. Testing}

Setelah selesai pembuatan aplikasi, maka dilanjutkan dengan tahap pengujian, pada pengujian ini menggunakan black box, tahapan ini merupakan pengujian produk yang telah melalui tahapan assembly untuk melihat kemungkinan adanya kesalahan pada tahapan ini penulis menggunakan pengujian black box untuk menguji produk, pengujian black box berfokus pada persyaratan fungsional perangkat lunak.

Pada pengujian aplikasi Virtual Tour kampus Unsrat ini menggunakan metode Black Box dan aplikasi ini berfungsi dengan baik sesuai yang di harapkan, dari hasil pengujian didapatkan beberapa hal yaitu, untuk menjalankan aplikasi ini membutuhkan koneksi internet yang baik untuk menampilkan halaman Bing Map dan spesifikasi laptop yang baik juga.

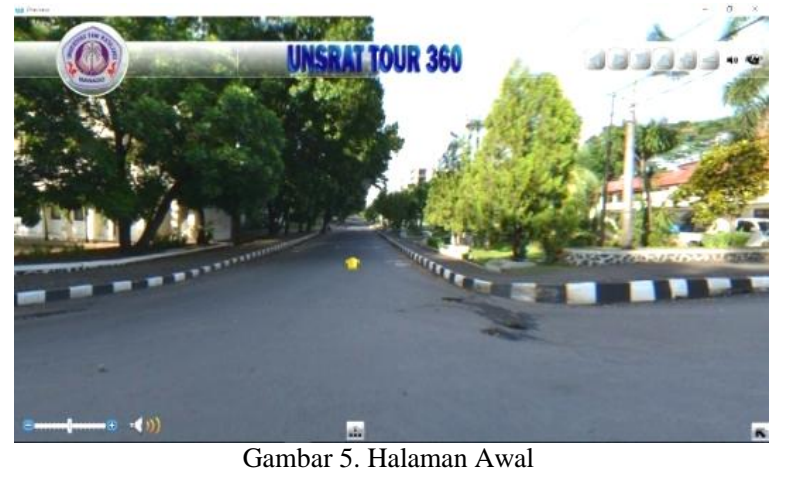



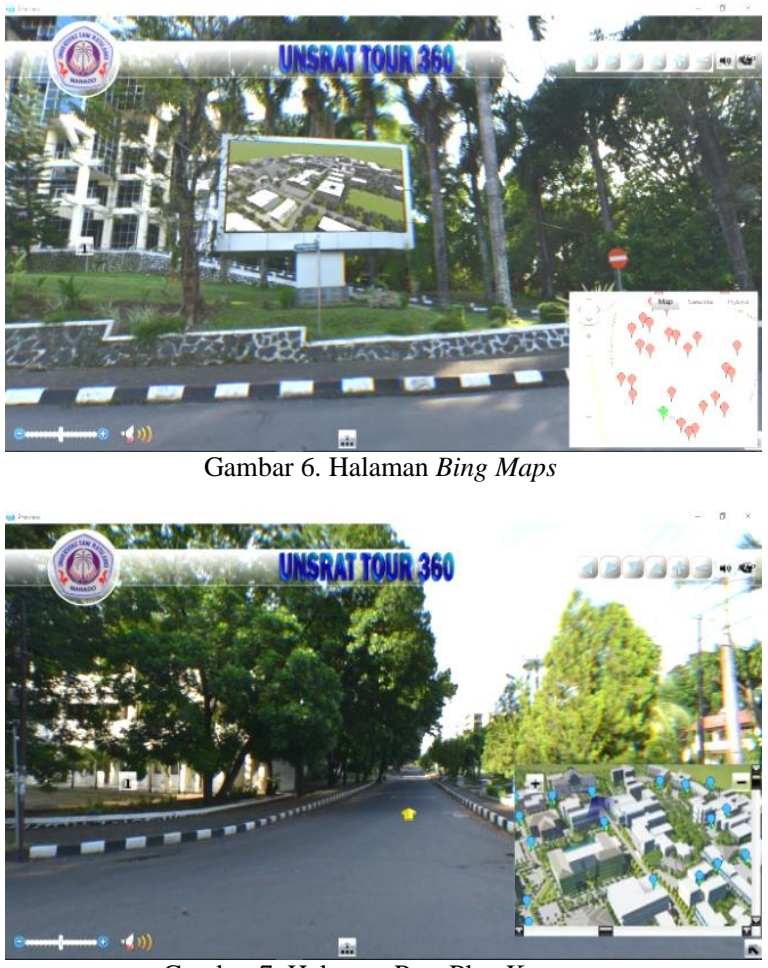

Gambar 7. Halaman Peta Plan Kampus

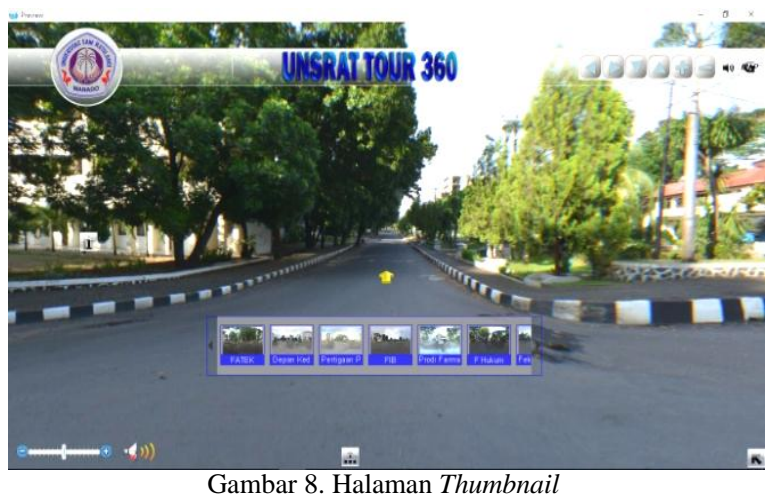

Pengujian tampilan awal (gambar 5) akan terlihat logo Kampus Universitas Sam Ratulangi Manado, tombol 'control bar', tombol 'thumbnail', tombol 'anak panah', tombol 'peta', tombol 'control putaran 360', dan tombol 'music' berfungsi dengan baik.

Pengujian halaman Bing Maps (gambar 6) harus terkoneksi internet terlebih dahulu, pada halaman awal user dapat mengklik tombol 'G Map' pada halaman Bing Maps aplikasi ini menyediakan beberapa tombol navigasi diantaranya tombol Map, Satelite, Hybrid dan tombol spot -spot lokasi, berfungsi dengan baik.

Pengujian Peta Plan Kampus (gambar 7) user dapat mengakses secara offline, dengan menekan tombol peta kampus, pada halaman ini aplikasi menyediakan beberapa tombol navigasi seperti tombol spot lokasi yang berwarna biru, dan tombol sistem radar fungsinya untuk mengetahui posisi putaran user, peta plan kampus berfungsi dengan baik.

Pengujian halaman Thumbnail (gambar 8) aplikasi ini akan menampilkan priview gambar-gambar lokasi panorama $360^{\circ}$ tombol Tumbnail berfungsi membantu user untuk mempercepat dalam pencarian lokasi 360 yang ingin dilihat, halaman Thumbnail berfungsi dengan baik.

\section{F. Distribution}

Setelah tahapan proses pengembangan seperti : concept, design, material collecting, assembly dan testing telah selesai dilakukan tahapan selanjutnya adalah distribution pada tahap ini yang dilakukan adalah mengkemas aplikasi Virtual Tour kampus menjadi format flash dan HTML5. Ukuran file aplikasi Virtual Tour kampus format flash adalah $296 \mathrm{MB}$ dan format HTML5 adalah $100 \mathrm{MB}$. Virtual Tour $360^{\circ}$ kampus Unsrat Manado juga dipublikasikan ke Google Maps dan Google Street View di situs resmi https://maps.google.com dengan kata kunci Unsrat. Dengan demikian Virtual Tour Panorama $360^{\circ}$ kampus Universitas Sam Ratulangi Manado dapat diakses oleh siapapun, kapanpun dan dimanapun secara online. Dapat dilihat pada gambar 9 .

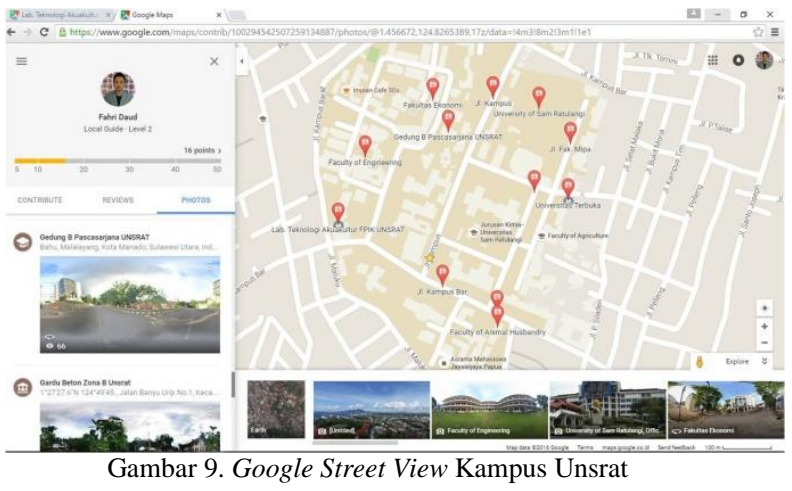

Google Street View Kampus Unsrat Manado (gambar 9) dapat dilihat pada situs resmi https://maps.google.com dengan kata kunci Unsrat.

\section{A. Kesimpulan}

\section{PENUTUP}

Berdasarkan penelitian yang dilakukan dalam mengembangkan aplikasi Virtual Tour Panorama 360 Derajat Kampus Universitas Sam Ratulangi Manado, penulis mengambil kesimpulan sebagai berikut :

1) Berdasarkan hasil kuesioner yang telah dilakukan kepada mahasiswa UNSRAT, bahwa sebagian mahasiswa 
UNSRAT belum mengenal semua lokasi di UNSRAT yaitu $79,8 \%$ dan mahasiswa memerlukan sebuah sistem untuk mempermudah dalam mengenal semua lokasi di UNSRAT yaitu $97,8 \%$.

2) Dalam mengkombinasikan gambar panorama $360^{\circ}$ dengan video, didapatkan kesimpulan bahwa spesifikasi video yang dapat berjalan pada gambar panorama $360^{\circ}$ yaitu video dengan Type file flv, jika menggunakan Type file MP4 ukuran video lebih besar, dan tidak dapat berjalan pada gambar panorama $360^{\circ}$ dalam aplikasi Virtual Tour Kampus UNSRAT.

3) Virtual Tour panorama $360^{\circ}$ Kampus Unsrat Manado dapat diakses secara online di situs resmi https://maps.google.com dengan kata kunci Unsrat.

4) Berdasarkan hasil pengujian menggunakan metode Black Box, aplikasi tersebut dapat berjalan dengan baik sesuai yang diharapkan.

B. Saran

Dalam penelitian ini tentunya masih terdapat banyak kekurangan dan hal-hal yang masih banyak yang perlu dikaji untuk dikembangkan lagi, maka dari itu dibuat saran untuk pengembangan lebih lanjut antara lain :

1) Menambahkan spot pengambilan gambar untuk dalam ruangan misalnya, Laboratorium, Kantor Administrasi Fakultas, Kantor Pusat UNSRAT, dll.

2) Untuk memotret panorama sebaiknya gunakan lensa macro fisheye, karena jika menggunakan lensa standar atau normal, gambar yang diperlukan untuk sebuah panorama membutuhkan pengambilan gambar lebih banyak.

3) Untuk pengembangan aplikasi ini kedepan, diharapkan pengembangan ke Virtual Reality agar lebih interaktiv dengan user.

4) Dalam desain interface aplikasi Virtual Tour ini dapat diperbaiki lagi untuk pengembangan lebih lanjut, agar terlihat lebih berkesan.

\section{DAFTAR PUSTAKA}

[1] Aznoora Osman, Nadia Abdul Wahab, Mohammad Hafiz Ismail, "Development and Evaluation of an Interactive $360^{\circ}$ Virtual tour for Tourist Destinations", Journal of Information Technology Impact, Vol 9, No. 3, pp. 173-182, 2009.

[2] Highton. Scot. 2010. Papper of Virtual Reality Photography Creating Panoramic and Object Images. China: Library of Congress.

[3] Luther, Arc C. 1994. Authoring Interactive Multimedia. Boston: AP Professional.
[4] Situs Resmi : https://www.ptgui.com/ [Diakses pada Rabu, 19 Agustus 2015]

[5] Situs Resmi : www.easypano.com [Diakses pada Kamis, 18 Februari 2016]

[6] Tay Vaughan. 2010. Multimedia Making It Work. United States

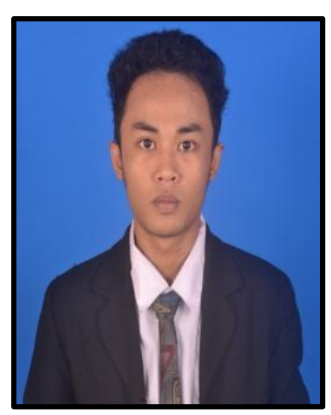

Sekilas dari penulis dengan nama lengkap Fahri Ramadhan Daud, lahir di kota Manado, Provinsi Sulawesi Utara. Anak ke-1 dari 3 bersaudara. Dengan pendidikan Sekolah Dasar Negeri 115 Manado. Kemudian Melanjutkan ke Sekolah Menengah Pertama Negeri SMPN 02 Manado. Kemudian melanjutkan ke Sekolah Menengah Kejuruan SMK N 3 Manado. Setelah lulus tahun 2011 melanjutkan ke Perguruan Tinggi di Universitas Sam Ratulangi Manado dengan mengambil Jurusan Teknik Informatika. Pada tahun 2016 bulan january, penulis membuat Skripsi demi memenuhi syarat Sarjana (S1) dengan penelitian berjudul Virtual Tour Panorama 360 Derajat Kampus Universitas Sam Ratulangi Manado yang dibimbing oleh dua dosen pembimbing yaitu Virginia Tulenan, S.Kom., MTI dan Xaverius B. N. Najoan, ST., MT sehingga pada tanggal 04 Agustus 2016 penulis resmi lulus di Teknik Informatika Universitas Sam Ratulangi Manado dan menyandang gelar Sarjana Komputer dengan predikat Sangat Memuaskan. 